\title{
はんだ接合強度に及ぼす無電解ニッケル-置換金めっき プロセスの影響
}

\author{
山本 智之 ${ }^{*}$, 渡辺 秀人 ${ }^{* *}$, 伊澤 和彦 ${ }^{* * *}$, 本間 英夫 ${ }^{* * *}$
}

\section{Effect of Electroless Nickel/Displacement Gold Plating Process on Strength of Solder Joint}

\author{
Tomoyuki YAMAMOTO ${ }^{*}$, Hideto WATANABE ${ }^{* *}$, Kazuhiko IZAWA $^{* * *}$ and Hideo HONMA ${ }^{* * * *}$
}

\author{
*関東学院大学大学院（テ 236-8501 神奈川県横浜市金沢区六浦東 1-50-1） \\ **小島化学薬品株式会社（厂 350-1335 埼玉県狭山市柏原 337-26） \\ ***株式会社野毛電気工業（２36-0004 神奈川県横浜市金沢区福浦 2-10-1） \\ ****関東学院大学工学部（２36-8501 神奈川県横浜市金沢区六浦東 1-50-1） \\ * Graduate School of Engineering, Kanto Gakuin University (1-50-1 Mutsuurahigashi, Kanazawa-ku, Yokohama-shi, Kanagawa 236-8501) \\ ** Kojima Chemicals \& Co., Ltd. (337-26 Kashiwabara, Sayama-shi, Saitama 350-1335) \\ *** Noge Electric Industries Co., Ltd. (2-10-1 Fukuura, Kanazawa-ku, Yokohama-shi, Kanagawa 236-0004) \\ ****Faculty of Engineering, Kanto Gakuin University (1-50-1 Mutsuurahigashi, Kanazawa-ku, Yokohama-shi, Kanagawa 236-8501)
}

\begin{abstract}
Electroless nickel plating has been applied for the formation of electronics circuits due to the downsizing of electronic components. However, solderability of electroless deposited nickel films is usually inferior to that of electrolytic deposited nickel films. In this paper, we focused on the relationship between the strength of solder joint and deposited nickel condition. Thickness of P-rich layer and morphology of the deposited nickel films affect the strength of solder joint. It was found that P-rich layers are formed at the subsurface of the deposited nickel and these layers are signifcantly changed after treatment of gold displacement. The strength of solder joints increases with decreasing P-rich layer. In this study, we found that the deposit condition of electroless nickel film also influences on the strength of solder joint.
\end{abstract}

Key Words: Electroless Nickel, Displacement Gold Plating Process, Strength of Solder Joint, P-rich Layer, Morphology of the Deposited Nickel Films

\section{1. 緒 言}

今日, BGA や CSP 基板などのはんだ接合を必要とする箇 所への無電解めっきの適用が増加している(1) 4)。しかし, 無電解めっきでは, 電気めっきと比較して, はんだ接合部 分の強度が低いという問題を抱えていた。これは, (1)無電 解ニッケルの析出時におけるリンリッチ層の形成, または, (2)はんだ接合時にニッケルーリンースズの合金層が形成され， はんだ接合強度を低下させていると解釈されており5),6)，し たがって, 無電解ニッケルーリンめっき皮膜中のリン含有 率を低下させることによって，はんだ接合強度が向上する との報告もなされている7)。しかし, これらの報告は, 無 電解ニッケルめっき時のリンリッチ層の分析や, はんだ接 合後の合金層の検討がほとんどである。

本報では, 無電解ニッケルめっきから置換金めっき間の 工程において, 無電解ニッケルめっき皮膜形態, またニッ ケルおよび置換金めっき後のリンリッチ層厚さの変化, 金 はく離後のニッケルめっき表面の形態, さらには, 無電解 ニッケルめっき皮膜の析出形態とはんだ接合強度との関係 を検討した。

\section{2. 実験方法}

\section{1 評価基板の作製}

はんだ接合強度，ニッケルおよび金めっき皮膜形態を観 察するために, $35 \mu \mathrm{m}$ 銅箔つき FR-4 材上に, 電気銅めっき $(18 \mu \mathrm{m})$ を施し，オーバーレジストタイプの径 $0.5 \mathrm{~mm}$ のは んだボールパッドを形成したものを使用した。慣用の前処 理を施した後, はんだパッド上に無電解ニッケルめっき皮 膜を約 $5 \mu \mathrm{m}$, 置換金めっき皮膜は約 $0.05 \mu \mathrm{m}$ 成膜した。

\section{2 置換金めっきプロセス}

無電解ニッケルめっき液は, リン含有率の異なるニッケ ルめっき皮膜を形成するために, A 浴から $\mathrm{G}$ 浴の 7 種のめっ き浴を用いた。これらのニッケルめっき浴のリン含有率と 特徵をTable 1 に示す。また, ニッケル成膜後, 置換金めっ き浴として亚硫酸金ナトリウムを金属塩とするノーシアン タイプを使用し, 浴温 $68^{\circ} \mathrm{C}$, 浴 $\mathrm{pH} 7.3$, 機械かくはん下で 金皮膜形成を行った。

\section{3 はんだボール接合強度測定}

リン含有率の異なる 2.2 項に示した 7 種の無電解ニッケル 浴を用いて FR-4 基板の銅めっき膜上にニッケルを成膜し, 
Table 1. P contents of nickel films and characteristics of nickel baths

\begin{tabular}{c|l|c}
\hline & P contents & Characteristics \\
\hline A Bath & about $4 \%$ & $\begin{array}{c}\text { Acetic Acid+Glycine Base } \\
+ \text { Sulfuric additive }\end{array}$ \\
\hline B Bath & about 6\% & $\begin{array}{c}\text { DL-Malic Acid+Succinic Acid Base } \\
+ \text { Sulfuric additive }\end{array}$ \\
\hline D Bath & about 6\% & DL-Malic Acid +Succinic Acid Base \\
\hline E Bath & about 6\% $8 \%$ & $\begin{array}{c}\text { Lactic Acid +DL-Malic Acid Base } \\
+ \text { Sulfuric additive }\end{array}$ \\
\hline F Bath & about $10 \%$ & $\begin{array}{c}\text { Lactic Acid + DL-Malic Acid Base } \\
+ \text { Sulfuric additive }\end{array}$ \\
\hline G Bath & about $12 \%$ & $\begin{array}{c}\text { Lactic Acid + DL-Malic Acid Base } \\
+ \text { Sulfuric additive }\end{array}$ \\
\hline
\end{tabular}

さらに置換金めっきを施した後，はんだパッド（直径 $0.5 \mathrm{~mm})$ に直径 $0.6 \mathrm{~mm}$ のはんだボール (Sn: $63 \%, \mathrm{~Pb}: 37 \%)$ を RMA タイプのフラックスを用い搭載した。さらに，置 換金めっき後に $200^{\circ} \mathrm{C}$ で 1 時間熱処理を施した場合も，同 様の方法ではんだボールを搭載した。両者のはんだボール 搭載条件は, プレヒート温度を $150^{\circ} \mathrm{C}$, リフロー温度を $230^{\circ} \mathrm{C}$ とした。た, はんだ接合強度測定は, 加熱式プル 強度測定装置（デイジ社製 4000 シリーズ）を使用し，プル スピード $300 \mu \mathrm{m} / \mathrm{s}$ で各々 20 か所測定を行い, その平均接 合強度を算出した。

\section{4 リン分布状態の観察}

無電解ニッケルめっきおよび置換金めっき後のリン分布 状態はオージェ電子分光法(AES)により観察した。また, Fig. 1 に示すように, リンを検出するのに必要なスパッ夕 リング時間 $(\mathrm{min})$ とスパッタリング速度 $(\mathrm{nm} / \mathrm{min})$ よりリン リッチ層の厚さ $(\mathrm{nm})$ を求めた。

\section{5 無電解ニッケルめっき皮膜形態の観察}

ニッケルめっき皮膜の表面形態は原子間力顕微鏡(AFM)

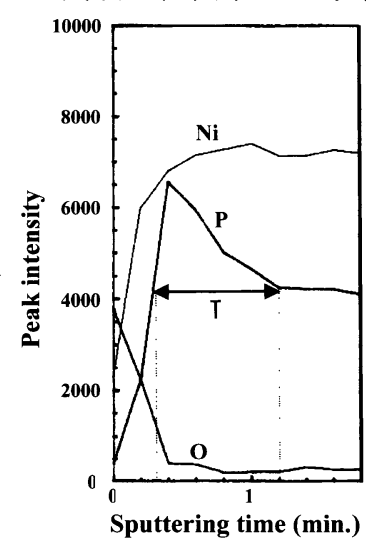

Thickness of P-rich layer $(\mathrm{nm})=\mathbf{T} \times \mathbf{S R}$

$\mathbf{T}=$ Sputtering time for disappearing P-rich layer (min.) $\mathrm{SR}=$ Sputtering rate $(\mathrm{nm} / \mathrm{min}$.)

Fig. 1 Calculation method of thickness of P-rich layer
により観察した。ニッケル皮膜の析出形態は，置換金めっ き後の評価基板を破断し，ニッケル皮膜の破壊面を走査型 電子顕微鏡 $(\mathrm{SEM})$ により観察した。置換金めっき皮膜はく 離後のニッケルめっき皮膜形態は, $40^{\circ} \mathrm{C}$ のアンン系金はく 離液に金めっきを施した基板を 30 秒間浸せきし，金はく離 後のニッケルめっき皮膜をSEMにより観察した。

\section{3. 実験結果}

\section{1 はんだ接合強度}

一般に, はんだ接合強度を低下させる原因としては, 無 電解ニッケルめっき反応時のリンリッチ層や, リフロー時 にはんだ-ニッケル間に形成されるスズ-ニッケルーリン層 に基づくと報告されている6)。リン含有率により，はんだ 接合強度は著しく異なると考えられたが, Fig. 2 に示すよ うに，ニッケル皮膜中のリン含有率にかかわらず， $\mathrm{A}$ 浴 (4\%), B浴 $(6 \%), \mathrm{G}$ 浴 $(12 \%)$ において，いずれの浴でもはん だ接合強度は十分な值が得られなかった。一方，B浴を除 いてニッケル皮膜中のリン含有率が，C浴 $(6 \%)$ の中リン夕 イプから中高リンタイプの F 浴 $(10 \%)$ では，はんだ接合強 度は良好であった。また，CやF浴よりも D $(6 \%)$ P 浴 $(8 \%)$ を用いた場合，高いはんだ接合強度を示し，さらには 熱処理前後におけるはんだ接合強度のばらつきが，その他 の浴と比較し相対的に小さくなっていることを確認した。 これは，BおよびC浴と $\mathrm{D}$ および $\mathrm{E}$ 浴ではニッケルの錯化 剂が異なるために，ニッケル皮膜の析出形態に顕著な差異 が生じたためであると考えられる。また，破壊箇所はすべ てはんだとニッケル界面から生じた。この結果から, 無電 解ニッケルめっき皮膜中のリン含有率の制御だけでは，は んだ接合強度は向上しないことが確認された。

\section{2 リのの分布状態}

一般に，はんだ接合強度に及ぼす因子の 1 つとしてリン リッチ層があげられる。そこで, 無電解ニッケルめっきと 置換金めっき時におけるリン分布状態を AES 深さ分析によ り観察し，代表例としてD浴を用いた結果を Fig. 3 に示す。

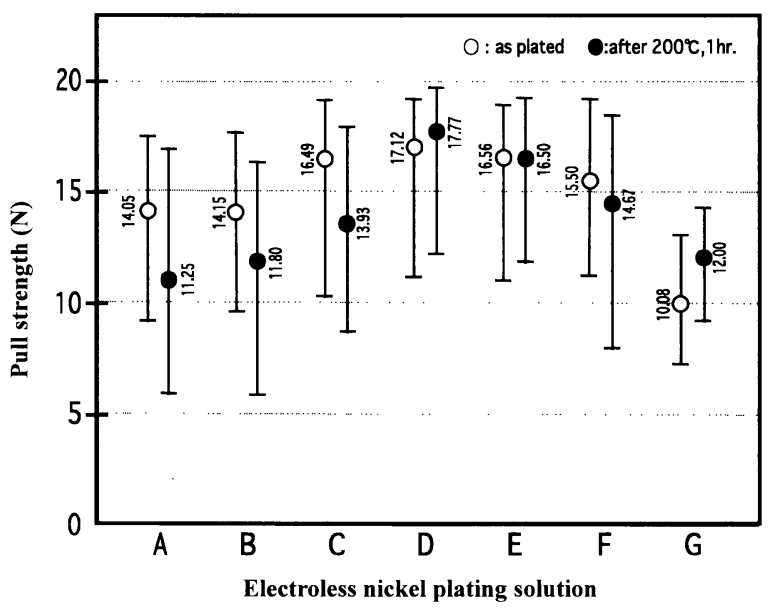

Fig. 2 Effects of electroless nickel plating solution on strength of solder joint 

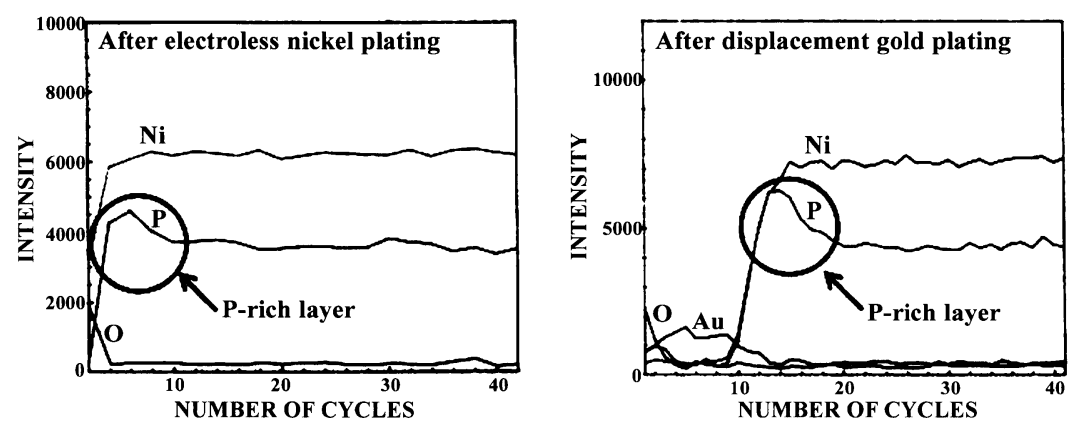

Fig. 3 AES depth profiles of deposited film after electroless nickel plating and displacement gold plating in the D solution

その他の浴についても同様にリンの分布状態を測定したが 無電解ニッケルめっき後のリンの分布状態は, いずれの めっき浴を使用した場合でも，皮膜表面層にリンのリッチ 層が確認された。これは, (II) 式のように, 次亜リン酸イオ ン自身が還元され，リンが生成し，このリンがニッケル めっき皮膜中に共析し，この過程において，過剩なリンが めっき最表面層に吸着, 拡散し, リンリッチ層が形成され たと考えられる ${ }^{8), 9)}$ 。

$\mathrm{NiSO}_{4}+2 \mathrm{NaH}_{2} \mathrm{PO}_{2}+2 \mathrm{H}_{2} \mathrm{O} \rightarrow \mathrm{Ni}+2 \mathrm{NaH}_{2} \mathrm{PO}_{3}+\mathrm{H}_{2} \uparrow+\mathrm{H}_{2} \mathrm{SO}_{4}$ (I)

$\mathrm{NaH}_{2} \mathrm{PO}_{2}+1 / 2 \mathrm{H}_{2} \rightarrow \mathrm{P}+\mathrm{NaOH}+\mathrm{H}_{2} \mathrm{O}$

$\mathrm{H}_{2} \mathrm{PO}_{2}^{-}+\mathrm{H}_{2} \mathrm{O} \rightarrow \mathrm{H}_{2} \uparrow+\mathrm{H}_{2} \mathrm{PO}_{3}^{-}$

一方，置換金めっき後のリンの分布状態は，無電解ニッ ケルめっき浴ごとに，リンリッチ層が顕著に変化した。こ れは, 金の置換めっき時にニッケルが溶出し, リンが溶出 せず残留する場合と，ニッケルとリンが同時に溶出する場 合が考えられる。したがって，リンリッチ層が増大する場 合と消失する場合があると推測される。そこで, 各無電解 ニッケルめっき浴を用い, 成膜後および置換金めっき後の リンリッチ層の厚さを調べた。その結果を Fig. 4 に示す。 低リンタイプの A 浴を用いた場合, 無電解ニッケルめっき 時に生じたリンリッチ層が，置換金めっき時に消失した。 これは, 低リンタイプのニッケル皮膜中のリン含有率が低 いので置換金めっき反応時に，ニッケルの溶出反応が激し

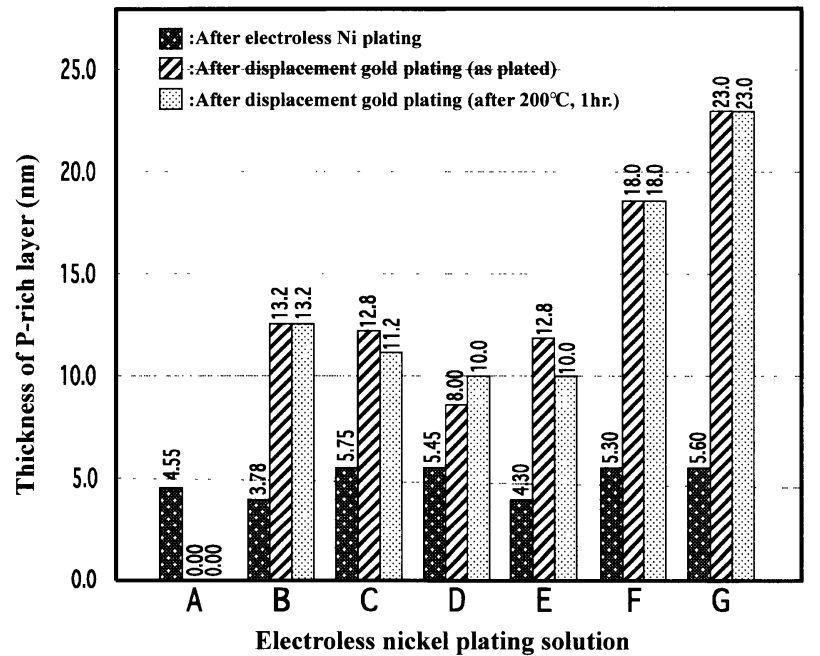

Fig. 4 Effects of electroless nickel plating solution on P-rich layer formation
く生起し，その際，ニッケル粒子間に偏析していたリンが 共に溶出したのではないかと考えられる。中リンタイプで ある $\mathrm{B}, \mathrm{C}, \mathrm{D}$ および $\mathrm{E}$ 浴を用いた場合， $10 \mathrm{~nm}$ 程度のリン リッチ層が形成された。このように同じようなリン含有率 であっても，置換金めっき後のリンリッチ層の厚さに顕著 な差異が確認された。これは，BおよびC浴とDおよび $\mathrm{E}$ 浴でニッケルの錯化剂が異なるために, ニッケルの析出状 態に差異が生じ，無電解ニッケルめっき皮膜と置換金めっ きとの反応性が異なったのではないかと考えられる。一方， $\mathrm{F}$ および $\mathrm{G}$ 浴を用いた場合, $20 \mathrm{~nm}$ 程度のリンリッチ層が形 成された。また，リンリッチ層の厚さは熱処理に影響され ないことがわかった。

\section{3 リンリッチ層の増加量}

以上のように無電解ニッケルめっき皮膜上に置換金めっ き皮膜を成膜した際, 各浴ごとにリンリッチ層の厚さに顕 著な差異を生じた。そこで，置換金めっき時のリンリッチ 層の変化量とはんだ接合強度との関係について調べた。そ の結果, Fig. 5 に示すように, リンリッチ層の増加に伴い, はんだ接合強度が低下する傾向を示した。また，A浴のよ うに，リンリッチ層が消失しても，はんだ接合強度が低下 する場合が確認された。さらに，F浴のように，リンリッ チ層の厚さが若干厚い場合でも, 高いはんだ接合強度を示 した。

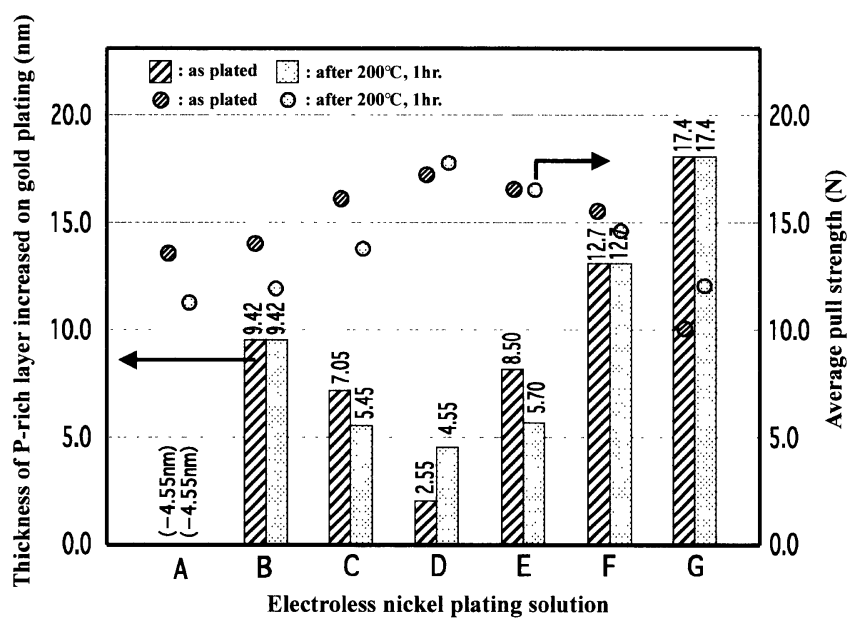

Fig. 5 Relationship between thickness of P-rich layer increased on gold plating and strength of solder joint 


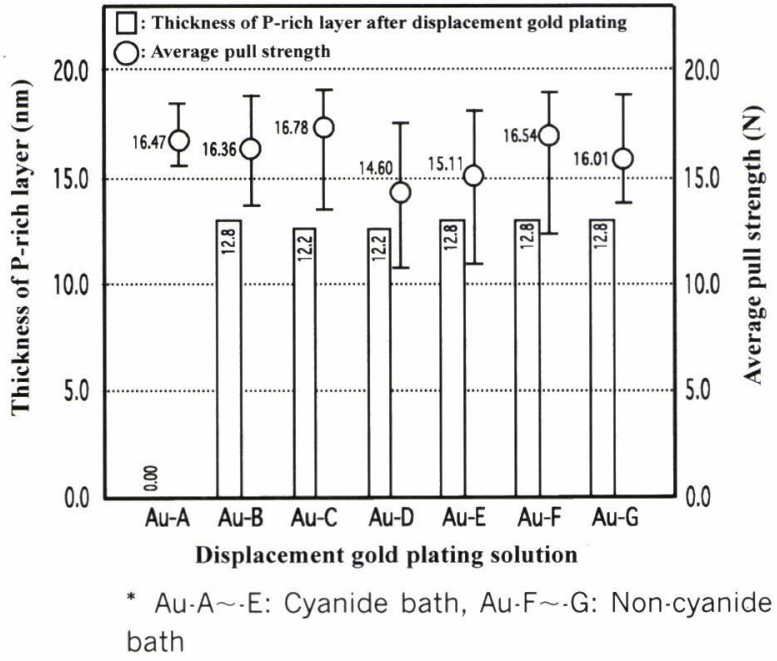

Fig. 6 Effects of 2 types of displacement gold plating solutions on P-rich layer formation and strength of solder joint

そこで, 無電解ニッケルめっき浴として E 浴を用いて, シアン浴 $(\mathrm{Au}-\mathrm{A} \sim-\mathrm{E})$ およびノーシアン浴 $(\mathrm{Au}-\mathrm{F} \sim-\mathrm{G})$ の置換 金めっきを用い， BGA 基板上にニッケルおよび金めっきを 行い, 2 種の置換金めっき後のリンリッチ層の厚さとはん だボール接合強度の関係を調べた。その結果, Fig. 6 に示 すように, リンリッチ層の厚さは $\mathrm{A} と \mathrm{~B} \sim \mathrm{G}$ 間で顕著な差 異が確認されたが, はんだ接合強度においては, 顕著な差 異が確認されなかった。これらの結果からも，はんだ接合 強度は, リンリッチ層の厚さのみに関与するものではなく 無電解ニッケルめっき皮膜の表面形態や析出形態もはんだ 接合強度に関与することが示唆された。

\section{4 ニッケルめっき皮膜の変色}

次に 3.1 項に示した 7 種の無電解ニッケルめっき浴を用い てニッケルを成膜し，つづいて置換金めっきを施した際の ニッケルの表面形態がどのように変化するかについて, 置 換金めっき皮膜をはく離し, 無電解ニッケルめっき皮膜表 面をSEMにより観察した。その結果をFig. 7 に示す。A浴 のように置換金めっき皮膜はく離後, 二ッケル粒界に溝や ニッケル粒子上に大きなピンホールが形成される場合は,
はんだ接合強度が低下した。また，BおよびC浴と比較し， $\mathrm{D}$ およびE浴はニッケル粒界およびニッケル粒子上で黒い 変色 (黒化) が認められたが, 高いはんだ接合強度を示 し，熱処理後の接合強度の低下は見られなかった。これは， $\mathrm{B} \sim \mathrm{D}$ 浴のリン含有率は同じであっても，二ッケルの錯化剂 が異なると, ニッケル析出形態が異なり, はんだ接合強度 に大きく影響していることを示している。また，G浴のよ うに，置換金めっき後に無電解ニッヶルめっき皮膜に黒い 変色が生じない場合でも, リンリッチ層の厚さが大幅に増 加する場合は，はんだ接合強度が低下した。そのため, ニッケル粒子間に形成される溝およびニッケル粒子上に形 成されるピンホールもはんだ接合強度に影響を及ぼすが, ニッケル粒子間および粒子上の黑い変色は, 必ずしも, は んだ接合強度低下の主因子であるとは断定できないことを 示している。

\section{5 ニッケルめっき皮膜の表面形態}

置換めっきは下地金属との電位差を利用し, 成膜反応が 進行する。したがって, 無電解ニッケルめっき皮膜の表面 形態および析出形態は，はんだ接合強度に大きな影響を与 えると考元れる。そこで, 無電解二ッケルめっき皮膜の 表面形態とはんだ接合強度の関係について調べた。その結 果をFig. 8 に示す。本検討で使用した無電解二ッケルめっ き後の皮膜の表面形態を 3 種類（分類 I III）に大別した。 ニッケル粒界が明確に認められ, 凹凸のあるニッケル皮膜 を分類 I とした。また，二ッケル粒界が明瞭に認められな いが平滑な部分と窪んだ部分が混在したニッケル皮膜を分 類 II しした。さらには，ニッケル粒界がなく，平滑なニッ ケル皮膜を分類正とした。分類亚のように, 無電解ニッケ ルめっき皮膜の平滑性が向上するに伴い，はんだ接合強度 が高くなる傾向を示した。これは，ニッケルめっき皮膜の 粒界が低下することで, 過剩なニッケルの溶出, 粒界間に 形成される溝の生成が抑制されたためであると考えられる。 しかし， G 浴のように二ッケル皮膜中のリン含有率が高く， 置換金めっき後のリンリッチ層の増加が著しく大きい場合， 表面形態が平滑にもかかわらず，はんだ接合強度が低下す

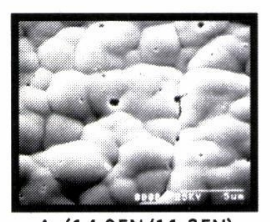

A $(14.05 \mathrm{~N} / 11.25 \mathrm{~N})$

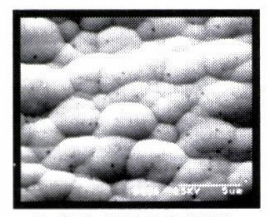

$E(16.56 \mathrm{~N} / 16.50 \mathrm{~N})$

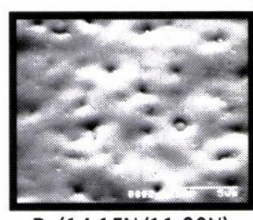

B $(14.15 \mathrm{~N} / 11.80 \mathrm{~N})$

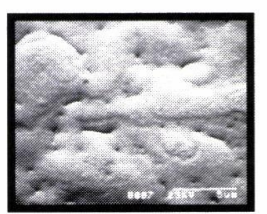

$\mathrm{F}(15.50 \mathrm{~N} / 14.67 \mathrm{~N})$

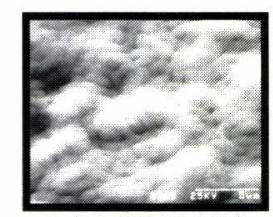

C $(16.49 \mathrm{~N} / 13.93 \mathrm{~N})$

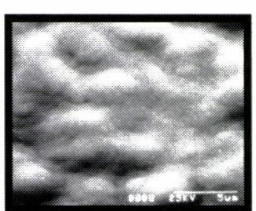

$\mathrm{G}(10.08 \mathrm{~N} / 12.00 \mathrm{~N})$

Thickness of P-rich layer : $23.0(\mathrm{~nm})$

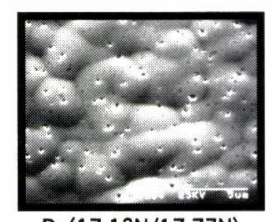

$\mathrm{D}(17.12 \mathrm{~N} / 17.77 \mathrm{~N})$

$=$ Average pull strength: as plated/after $200^{\circ} \mathrm{C}, 1 \mathrm{hr}$.

Fig. 7 Surface morphologies of electroless nickel plating film after removal of deposited gold film 


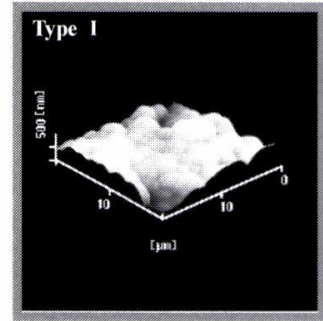

$A(14.05 \mathrm{~N} / 11.25 \mathrm{~N})$ $E(16.56 \mathrm{~N} / 16.50 \mathrm{~N})$

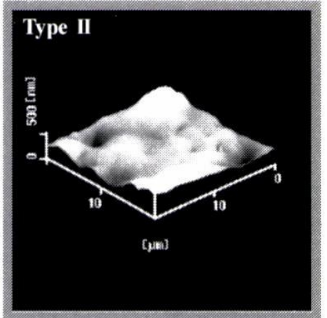

$B(14.15 \mathrm{~N} / 11.80 \mathrm{~N})$ $\mathrm{F}(15.50 \mathrm{~N} / 14.67 \mathrm{~N})$

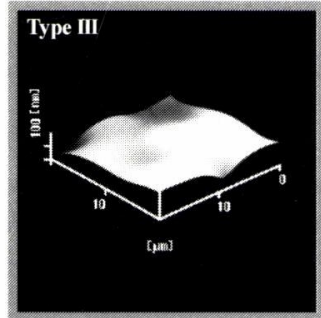

C $(16.49 \mathrm{~N} / 13.93 \mathrm{~N})$

$\mathrm{D}(17.12 \mathrm{~N} / 17.77 \mathrm{~N})$

$\mathrm{G}(10.08 \mathrm{~N} / 12.00 \mathrm{~N})$

* ( )=Average pull strength: as plated/after $200^{\circ} \mathrm{C}, 1 \mathrm{hr}$.

Fig. 8 AFM images of deposited electroless nickel film

ることを確認した。さらに，C浴のようにニッケル皮膜形 態が平滑であっても, 熱処理後のはんだ接合強度が低下す る場合も確認された。一方，E浴のように粒界が明瞭に認 められても，はんだ接合強度が高い場合も観察された。

\section{6 ニッケルめっき皮膜の析出形態}

一般には，上述の結果からニッケル析出皮膜の平滑化に 伴って，はんだ接合強度は向上する傾向を示した。しかし， E浴のように析出粒界が明瞭に認められる場合でも, 高い はんだ接合強度が得られた。そこで, 無電解ニッケルめっ き後の皮膜の析出形態とはんだ接合強度の関係について調 ベた。その結果をFig. 9 に示す。E浴のように，ニッケル めっき皮膜の表面形態に凹凸がある場合でも断面観察の結 果は層状析出であり，一方，B浴のように表面形態が平滑 な場合でも，はんだ接合強度が低い場合は，柱状析出に なっていることがわかった。しかも，AＣ浴のように柱状 析出の場合, 熱処理後の強度低下が大きくなる傾向を示し た。さらには，層状析出の場合でも， G 浴のように，リン リッチ層が $20 \mathrm{~nm}$ 以上になるとはんだ接合強度が低下する ことがわかった。

\section{7 はんだ接合強度と各因子}

以上の結果から, リンリッチ層は無電解ニッケルめっき 時に形成され，さらに置換金めっき時にそのリンリッチ層 の厚みが変化することがわかった。またFig. 10 に示すよう に，はんだボール接合時に金およびニッケルの一部がはん
だに拡散しははんだ-ニッケル間にリンリッチ層が形成さ れ，はんだ接合強度に大きな影響を与えた。そこで，はん だ接合強度に対する影響因子の関係を Fig. 11 にまとめた。 はんだ接合強度に及ぼす主因子として置換金めっき時に形 成されるリンリッチ層の厚さがあげられ，無電解二ッケル めっき皮膜の置換金めっきとの反応性, 表面形態および析
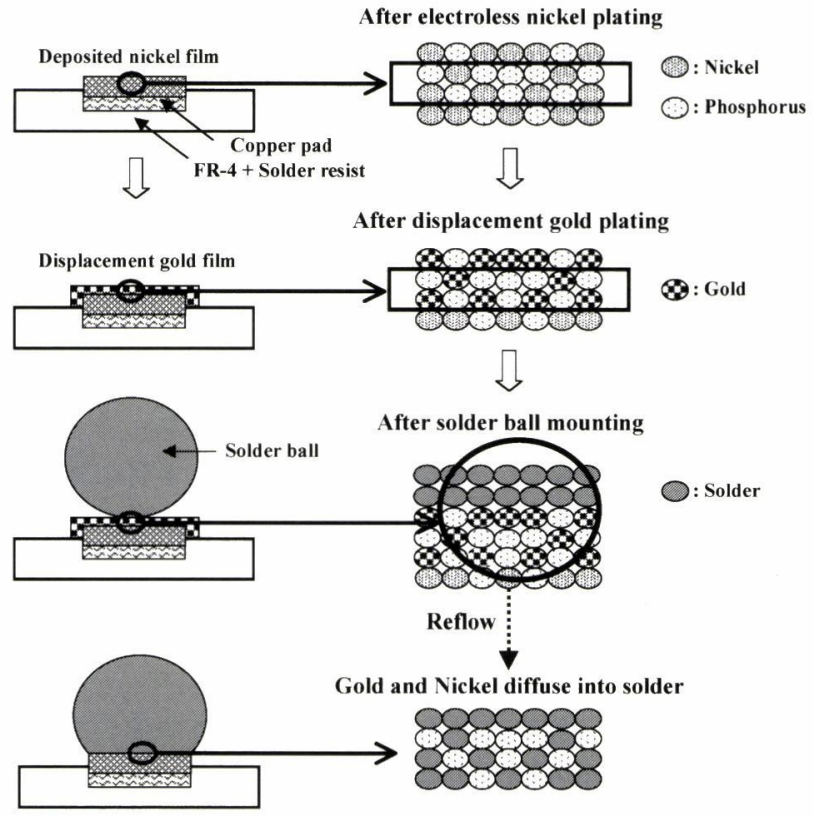

Fig. 10 Formation mechanism of P-rich layer between solder and nickel

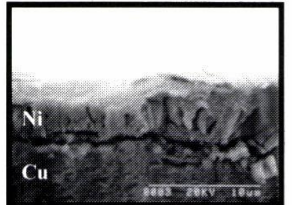

$A(14.05 \mathrm{~N} / 11.25 \mathrm{~N})$

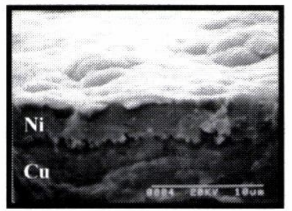

$E(16.56 \mathrm{~N} / 16.50 \mathrm{~N})$

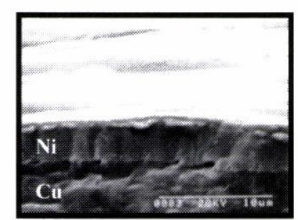

B $(14.15 \mathrm{~N} / 11.80 \mathrm{~N})$

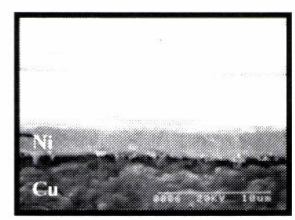

$\mathrm{F}(15.50 \mathrm{~N} / 14.67 \mathrm{~N})$

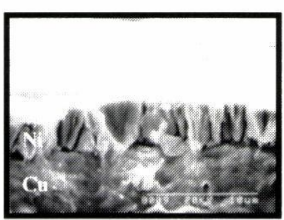

C (16.49N/13.93N)

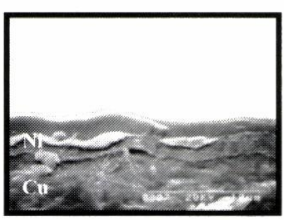

$\mathrm{G}(10.08 \mathrm{~N} / 12.00 \mathrm{~N})$

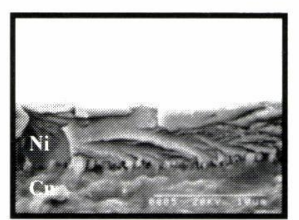

$D(17.12 \mathrm{~N} / 17.77 \mathrm{~N})$

( ) $=$ Average pull strength: as plated $/$ after $200^{\circ} \mathrm{C}, 1 \mathrm{hr}$.

Fig. 9 Cross sectional images of deposited nickel films on copper pad 

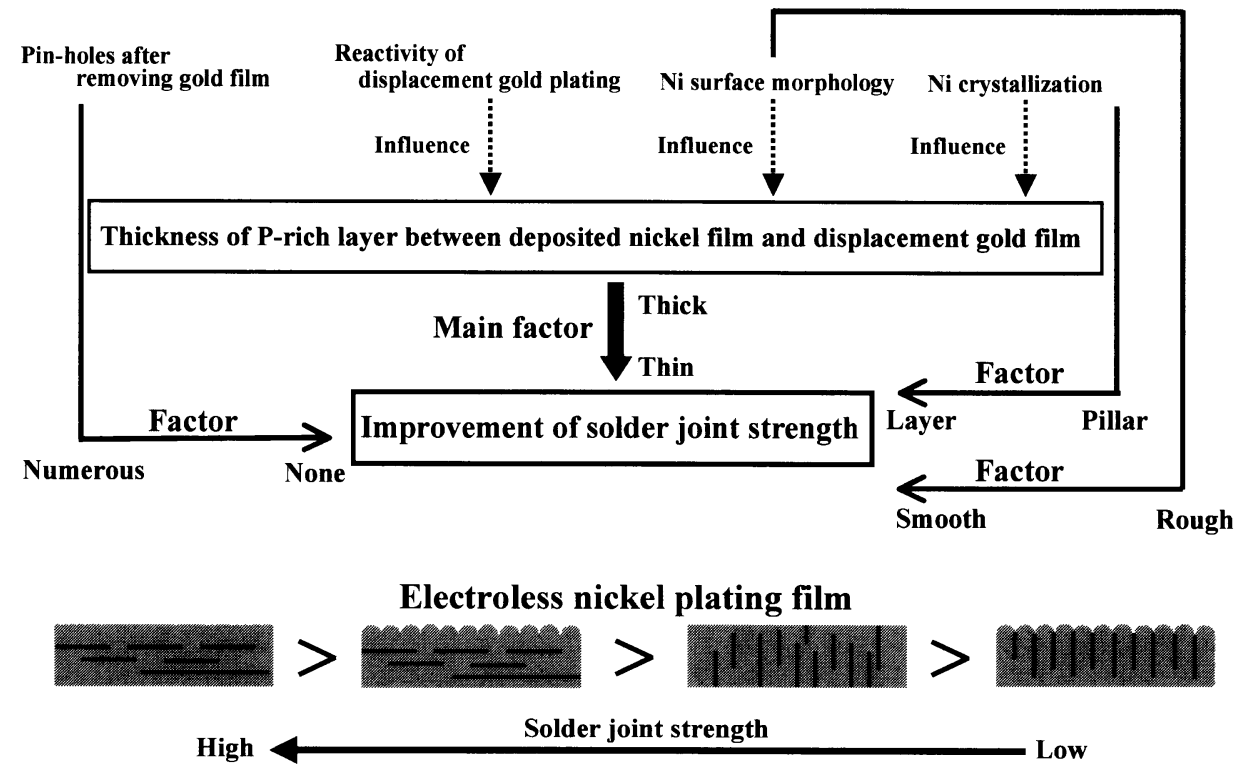

Fig. 11 Key factors for improvement of strength of solder joint

出形態も直接的もしくは間接的にはんだ接合強度に関与す ることを確認した。以上の結果から無電解ニッケルめっき 皮膜中のリン含有率を $6 \sim 8 \%$ に制御し, 層状析出でしかも 平滑性に優れた無電解ニッケルめっき皮膜を用いることで, 良好なはんだ接合強度が得られる傾向を示した。

\section{4. まとめ}

はんだ接合強度に及ぼす無電解ニッケル-置換金めっき の影響について検討を行い，以下の結論を得た。

1) リンリッチ層は, 無電解ニッケルめっき時に形成さ れ，ニッケル皮膜中のリン含有率，析出形態の違いに より，さらに置換金めっき後にリンリッチ層の厚みは 変化した。一方, 熱処理前後ではリンリッチ層に顕著 な変化は見られなかった。

2) 置換金めっき後のリンリッチ層の厚さが薄い方がは んだ接合強度が高くなる傾向を示した。

3）無電解ニッケルめっきのリン含有率や析出形態はは んだ接合強度に大きく影響を及ぼすが，置換金めっき の影響は少ないことがわかった。

4) 置換金めっきを施した後の下地のニッケル皮膜形態 を，金をはく離し観察した際に，ニッケル粒子間の溝 や粒子上のピンホールが形成された場合，はんだ接合 強度が低下した。また，ニッケル皮膜の変色とはんだ 接合強度との相関性は見られなかった。

5）無電解ニッケルめっき皮膜構造が層状の場合，はん だ接合強度が高くなる傾向を示した。

6) 無電解ニッケル-置換金めっき皮膜間のリンリッチ首 が $10 \mathrm{~nm}$ 以下，析出皮膜構造が層状，表面形態が粒界 フリー, さらに平滑性に優れた無電解ニッケルめっき 皮膜は, 良好なはんだ接合強度が得られる傾向を示し た。

(2002.11.12-受理)

\section{文献}

1) 珍田 聡, 宮本宣明, 吉岡 修: “無電解金めっき $\mathrm{TAB}$ テープ材の金めっき厚さとはんだボール接合信頼性”，エレ クトロニクス実装学会誌, Vol. 3, No. 4, p. 308, 2000

2) 谷口文彦, 安藤史彦, 高島 晃: “FBGA のはんだ接合部の 熱度労および機械的信賴性”，エレクトロニクス実装学会 誌, Vol. 4, No. 1, p. 56, 2001

3) 大田広徳, 百川裕希, 河野英一, 恒益喜美男, 田中靖則 : “CSP実装基板における曲げ試験での破壊モードと寿命”, エレクトロニクス実装学会誌, Vol. 4, No. 6, p. 519, 2001

4) 大和電機工業: “半導体パッケージ基板用無電解 $\mathrm{Ni} / \mathrm{Au}$ めっ き技術”，最先端実装技術・パッケージング展製品技術セ ミナー特別講演予稿集, p. 67, 2002

5）松木浩久, 井深 洋, 坂 公恭：“半導体デバイスにおけ る半田接合界面の TEM 観察”, 日本金属学会誌, Vol. 64, No. 3, p. 213, 2000

6）苅谷義治，中村久美子，大塚正久, 田中晴則：“無電解 $\mathrm{Ni}-\mathrm{P} / \mathrm{Sn}-\mathrm{Ag}$ はんだ接合部の界面組織と機械的信頼性”，6th Symposium on Microjoining and Assembly Technology in Electronics 要旨集, p. 415, 2000

7) 杉崎 敬, 田嶋和貴, 佐々木 忠, 中尾英弘, 福田 豊, 木村 隆：“BGAはんだ接合に及ぼす無電解 $\mathrm{N} / \mathrm{Au}$ 処理の 影響”，エレクトロニクス実装学会誌，Vol. 4, No. 2, p. 124, 2001

8）電気鍍金研究会編：“無電解ニッケルめっきの析出機構一 無電解めっき基礎と応用”，日刊工業新聞社，p. 27, 2001

9）田代雄彦, 山本誠二, 石川 薰, 中里純一, 本間英夫： “無電解 NiPめっき皮膜中におけるリン分布状態”，エレク トロニクス実装学会誌，Vol. 5, No. 4, p. 359, 2002 